\title{
VALUE CREATION NETWORKING DIMENSION DOMINATION ON ENTREPRENEURIAL MARKETING BEHAVIOR: A PERSPECTIVE OVERVIEW OF COMPANIES MANAGED BY FOUNDERS AND PROFESSIONALS
}

\author{
Hendro Susanto ${ }^{*}$ and Christina Whidya Utami ${ }^{1}$ \\ ${ }^{1}$ Business Management, University of Ciputra, Surabaya, Indonesia
}

\begin{abstract}
The aim of this study is to fill the gap in the study of Entrepreneurial Marketing behavior. Previous studies are found to be insufficient in determining the most dominant dimension that contributes to the differences in entrepreneurial marketing behavior when implemented in companies with certain characteristics. Entrepreneurial marketing dimension in this study focuses on Growth Orientation, Opportunity Orientation, Total customer focus, Value creation Networking, Informal Market Analysis, Closeness to The Market, and whether those factors result in differences in the behavior of founders and professionals in managing companies. The study was conducted on 406 business owners in 8 provinces in Indonesia. Snowball sampling was used to select the respondents from the overall company population in Indonesia, be it services or manufacturing company. The result of the study indicates that lower Entrepreneurial Marketing behavior is found in companies managed by founders compared to companies managed by professionals. This study also contributes to findings on Value Creation Networking dimension that is proven to be the most dominant dimension in influencing Entrepreneurial Marketing behavior, be it for founders or professionals in managing companies.
\end{abstract}

\author{
ARTICLE HISTORY \\ Received:5-12-2019 \\ Accepted:24-2-2020
}

\section{KEYWORDS}

Entrepreneurial Marketing

Growth Orientation

Opportunity Orientation

Total Customer Focus

Value Creation

Networking

Informal Market Analysis

Closeness to The Market

\section{INTRODUCTION}

Entrepreneurial Marketing (EM) as a research field was first developed in the 1980s, whereas the domain of EM at that time has yet to become a well-known research field. EM began as an intercept between marketing and entrepreneurship and integrated into a general concept that frequently appears in research on marketing as well as entrepreneurship (Morris et al., 2002). At the development stage, there were plenty of discussions on the pros and cons of EM. One of the reasons for the EM concept to surface is it acts as a critique of the customer-centric model on marketing that results in a lack of innovation. This situation has resulted in process, product, and service replication that are relatively similar, and not as an innovative result (Sheth et al., 1991). EM approach can proactively make use of innovation and help manage risk in the process of product creation, communication, and value for customers (Miles and Darroch, 2006).

EM research has resulted in thoughts of EM as a marketing practice that helps companies to operate in a fast-changing environment. Previous studies contributed to identifying several EM behavior characteristics, such as decision-making (Carson and Grant, 1998), resources decision making (Thomas et al., 2013), decision based on intuition and experience (Hills and Singh, 1998), focus on opportunity identification, flexible approach to market and exploiting smaller market niche (Stasch, 1999). The aforementioned studies have justified that EM behavior is proven to be different in companies managed with different styles and approaches. The conclusion is based on several initial research that shows startup companies are more successful in executing entrepreneurial marketing. Similarly, big companies will be more successful in executing entrepreneurial marketing.

The majority of EM research is usually conducted using a case study approach, in which although the result will give a detailed illustration of company experiences, it can't be generalized in various samples with certain characteristics. Several studies were also not focusing on researching which dimension is more dominant and contributes to entrepreneurial marketing behavior when implemented in companies with different company management characteristics. The study aims to fill this gap by analyzing EM dimensions in companies managed by founders compared to companies managed by professionals. Contribution expected of this study in the development of EM knowledge is how big is the difference in the implementation of entrepreneurial marketing behavior between companies with different managing subjects (founders or professionals), as well as which dimension is dominant in contributing to entrepreneurial marketing behavior in companies managed by both founders in comparison to professionals. 


\section{LITERATURE REVIEW}

\section{Entrepreneurial marketing dimension}

According to Kraus et al (2012), EM is defined as an organizational function and a set of processes to create innovation, communicate, and give value to customers, as well as manage the relationship with customers in a way that benefits the organization and its shareholders. This is indicated by innovation, risk-taking, proactive measures, and can also be done without resources that are currently owned by the organizations. Various combinations of EM dimensions have also been frequently researched in various studies. Though fragmented, several researchers have collectively shaped the EM paradigm (Collinson \& Shaw, 2001; Jones \& Rowley, 2011). Morris et al (2002) developed 7 core dimensions in EM, which are: proactiveness, calculated risk-taking, innovativeness, opportunity focus, resource leveraging, costumer intensity, and value creation. These dimensions differentiate the EM approach from the traditional marketing approach. However, the dimensions used in this study are taken from Morris et al (2002) and several other studies. These dimensions are Growth Orientation, Opportunity Orientation, Total customer focus, Value creation Networking, Informal Market Analysis, Closeness to The Market.

\section{Growth orientation}

Marketers in general have a long-term goal to achieve sales growth through a long-term relationship in their marketing activities (Kilenthong et.al, 2015). On the other hand, EM is always related to growth. Marketer ambition to grow the company will decide the company business model, competitive strategy, and resource management strategy of the company. In order to facilitate growth, marketers can adopt several ways to develop their businesses, including increasing repeating business and creating a community of customers who are dedicated and loyal to the products.

\section{Opportunity orientation}

Companies can be considered as an entity that is constantly trying to find new ways to improve product and services offered with a number of risks entailed (Becherer et al., 2008). Opportunity is a source of continuous profit for companies. The availability of opportunity is highly related to the level of change in the environment which is an indication for marketers to always look for and discover the said opportunity (Hacioglu et.al, 2012). Even though opportunities can appear randomly, EM is known to proactively seek new opportunities. EM puts emphasis on pursuing opportunity while still taking into consideration existing resources. Innovation and creativity are important processes in helping EM to turn opportunity into reality. Companies that adopt EM often focus on creating a new product category and directing their customers using unsustainable innovation. Note that innovation is not only limited to products or services but also includes the marketing process and strategy.

\section{Total customer focus}

Marketers integrate their customers into their operation and regularly accepts recommendations from their customers. Customer preferences directly affect and play an important role in determining product approach, price, distribution, and communication of a company. EM behavior prioritizes customer preferences using a very focused and flexible approach and can be adjusted to the market. EM behavior allows companies in making new promises to customers, modifying their product design, and changing their prices to give the most satisfactory product or service to their customers (Becherer et al., 2008; Morris et al., 2002). EM makes customers their top priority and treats customers as active participants in the process of marketing decision making.

\section{Value creation networking}

Resources from the network can help companies manage their risk and allocate their resources more efficiently. Note that the entrepreneurial marketer network is not only limited to suppliers and customers but also includes competitors. Through competitors, companies can also gain knowledge and resources that are previously not owned (Gilmore, Carson \& Grant, 2001). Value creation through a network is an important concept in EM. EM gathers market information and gains access to potential customers through their network (Kilenthong et.al, 2015). Information from the network can also help marketers to offer high-quality products with the best quality to the customers to gain a competitive advantage against the competitors.

\section{Informal market analysis}

Marketers have the tendency to not conduct research in the formal market since they believe that they gain intuitive and useful understanding about their market from discussions and various informal information collected from their customers (Li et.al, 2009). Marketing decisions under EM do not always depend on a formal planning process (Hills \& Hultman, 1999). A company marketing strategy can be initiated and adjusted during implementation. Entrepreneurial marketers often follow their intuition in making marketing decisions and consider intuitive assessment as a very important aspect in assessing market potential.

\section{Closeness to the market}

Several EM practitioners rely on experience when deciding on new products and services because they believe that experience helps make competent marketing decisions (Kilenthong et.al, 2015). EM often has a decision-making process 
that is closely related to customers. They make decisions based on customers' feedbacks or information received from direct interactions or face-to-face conversations with customers. A marketer can gather information about the market through the relationship with supplier and sales partner, and changes in customers' preferences. This information enables them to implement marketing strategy and communication more effectively.

\section{Hypotheses}

Experience, value, and personality of the top management not only affect management decisions, but also structure, function, and company performance (Hambrick \& Mason, 1984; Randoy \& Goel, 2003). Previous studies have proven that professionals have several entrepreneurial qualities at a higher level compared to company founders. These qualities include self effectiveness in creating innovation, entrepreneurial competence and commitment, needs and accomplishments, tendency to take risks, and tolerance towards ambiguity (Erikson, 2002). Company founders are also reported to behave differently from professionals when deciding since they tend to be biased in decision making and heuristic as opposed to professionals (Busenitz \& Barney, 1997). Based on these studies, it was shown that professionals are more entrepreneurial compared to founders, and EM behavior is more common in companies operated by professionals compared to companies managed by founders. In relation to this statement, several hypotheses are proposed as follows:

H1. Companies managed by professionals have higher entrepreneurial marketing behavior level compared to companies managed by founders

H2. Value creation networking dimension is more dominant in companies managed by founders than companies managed by professionals

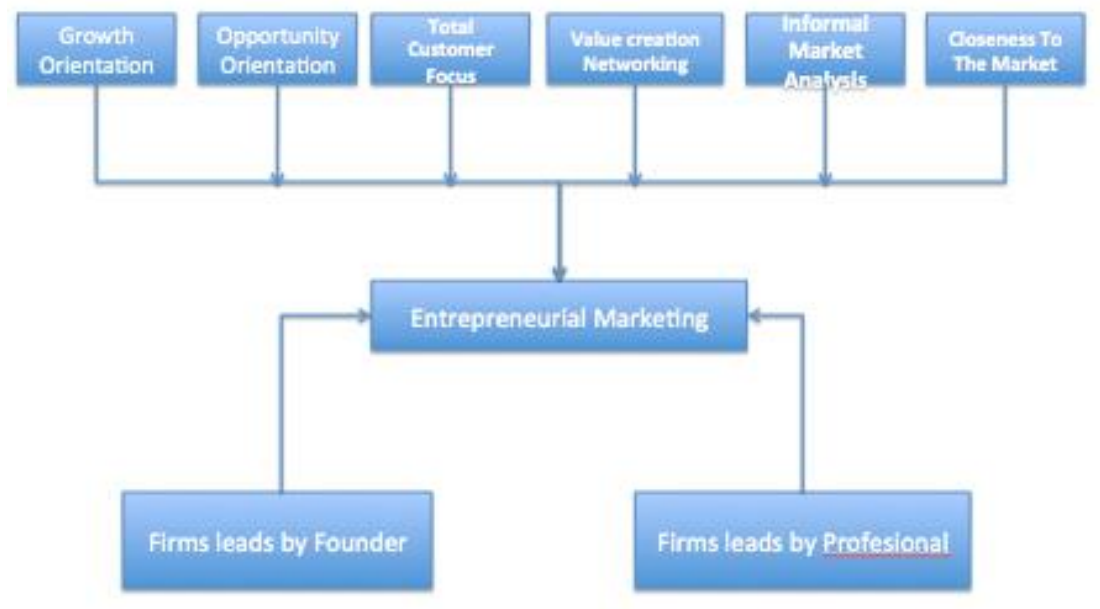

Figure 1. Conceptual model

Source: Processed by Researcher, 2019

\section{METHODOLOGY}

\section{Research methodology}

This research was conducted using a quantitative approach, since the systematical calculation of the difference between EM behavior in companies managed by founders and managed by professionals is needed, and also to determine the most dominant entrepreneurial dimension in entrepreneurial marketing behavior in companies managed by founders and managed by professionals. Both objectives emphasize hypothesis testing by using a statistical tool and trying to draw generalized conclusions.

The population of this study consists of 8 provinces in Indonesia (East Java, Central Java, West Java, Special Region of Yogyakarta, South Sumatra, Bali, South Sulawesi, South Kalimantan). Snowball sampling was used to determine the selected respondents. The sample in this study consists of 406 business owners spread throughout 8 provinces in Indonesia. Companies managed by founders are defined as companies with the majority or full control in the hands of the owners, whereby companies managed by professionals are companies that the founders have entrusted the management to professionals. The analysis techniques used to test the hypotheses proposed are t-test testing and multiple regression.

\section{Research model}

EM behavior is a dependent variable in this study. Independent variables are categorized based on EM dimensions which are growth orientation, closeness to market, value creation through networking, and informal market analysis. Five points Likert scale was used in the questionnaire which is agree, slightly agree, disagree, slightly disagree, or strongly disagree. 


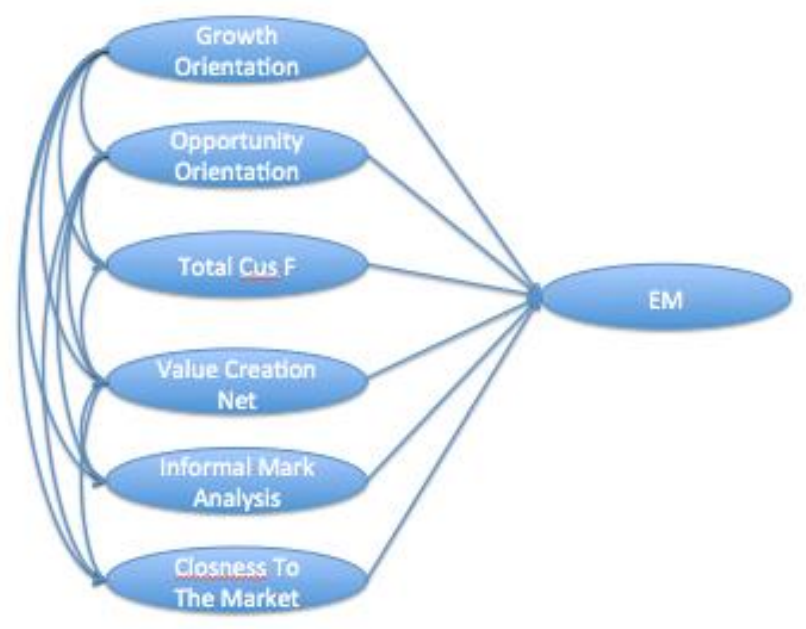

Figure 2. Research model

Source: Processed by Researcher, 2019

\section{Respondents descriptions}

The 406 companies in the sample are described in Table 1 below:

Table 1. Respondents descriptions

\begin{tabular}{l} 
Descriptions of Respondents \\
\hline Respondents consist of $280(68.9 \%)$ companies managed by founders and $126(31 \%)$ companies managed by \\
professionals. \\
Based on the company age, $31 \%$ aged less than 5 years, $58 \%$ aged between $5-15$ years, and $45 \%$ aged less \\
than 15 years. \\
Based on company assets, $23 \%$ of the companies have assets between $200-500$ million, $37 \%$ with assets more \\
than 500 million to 10 billion, and $40 \%$ with assets more than 10 billion. \\
Based on type of industry as follows: $3 \%$ service, $10 \%$ manufacturing, $3 \%$ real estate, $7 \%$ retail, $3 \%$ medical \\
equipment industry, $3 \%$ biotechnology, $3 \%$ refined sugar, $3 \%$ property, $3 \%$ food and beverage, $3 \%$ retail \\
houseware, $3 \%$ coffee processing, $3 \%$ trading company, $3 \%$ hospitality, $7 \%$ freight forwarding and logistic, \\
$3 \%$ fishery, $7 \%$ batik industry, $3 \%$ paint company, $3 \%$ agency, $7 \%$ furniture, $10 \%$ digital industry, $7 \%$ \\
branding and graphic design. \\
Based on new product or service launch in the business with details as follows: $58 \%$ of the companies have \\
launched new product or service $\leq 2$ years, $26 \%$ of the company has launched new product or service in $5.5 \leq$ \\
10 years and $2 \%$ of the company has launched new product or service in $\leq 10.5$ years. Therefore, more than \\
half of the companies in the sample have launched a new product or service in less than 2 years. \\
$96 \%$ of the sample strongly agrees to appreciate all processes related to innovation and only $4 \%$ slightly \\
disagrees or disagrees with the innovation process.
\end{tabular}

In addition, respondents' answers to each question in the questionnaire can be seen in Table 2 below: 
Table 2. Respondents' responses mean and standard deviation

\begin{tabular}{|c|c|c|c|}
\hline Indicator & Question & Mean & $\begin{array}{c}\text { Std. } \\
\text { Deviation }\end{array}$ \\
\hline G1 & Long term growth is more important than immediate gain & 4.5 & 0.7593 \\
\hline G2 & Our main purpose is to grow the business & 4.633 & 0.5405 \\
\hline G3 & We aggressively try to expand our customer base & 4.1601 & 0.9514 \\
\hline $\mathrm{O} 1$ & We keep searching for new business opportunities & 4.4113 & 0.73419 \\
\hline $\mathrm{O} 2$ & Our marketing effort leads the customer, and not to respond & 3.4704 & 1.33809 \\
\hline $\mathrm{O} 3$ & $\begin{array}{l}\text { Adding innovative product or service is very important to our } \\
\text { success }\end{array}$ & 4.5 & 0.73954 \\
\hline $\mathrm{O} 4$ & Creativity stimulates good marketing decision & 4.5739 & 0.65032 \\
\hline $\mathrm{T} 1$ & $\begin{array}{l}\text { Majority of our marketing decisions is based on what we learnt } \\
\text { from daily contact with the customers }\end{array}$ & 4.2833 & 0.80189 \\
\hline $\mathrm{T} 2$ & $\begin{array}{l}\text { Our customers require us to act flexibly and according to their } \\
\text { specific needs }\end{array}$ & 4.0739 & 0.97851 \\
\hline $\mathrm{T} 3$ & Everyone in this company make customers their main priority & 4.5123 & 0.71912 \\
\hline $\mathrm{T} 4$ & $\begin{array}{l}\text { We adjust ourselves quickly to fulfill our customers' } \\
\text { everchanging expectations }\end{array}$ & 4.4532 & 0.67515 \\
\hline V1 & We learn from our competitors & 4.4039 & 0.81612 \\
\hline $\mathrm{V} 2$ & $\begin{array}{l}\text { We use our friends and main industry partners extensively to } \\
\text { help us in developing and marketing our products and services }\end{array}$ & 4.2931 & 0.86084 \\
\hline V3 & $\begin{array}{l}\text { Majority of our marketing decisions is based on information } \\
\text { exchange with people in our personal and professional network }\end{array}$ & 4.1897 & 0.81103 \\
\hline I1 & $\begin{array}{l}\text { Introducing new product or service usually only involves } \\
\text { limited research and formal market analysis }\end{array}$ & 3.1059 & 1.41635 \\
\hline $\mathrm{I} 2$ & $\begin{array}{l}\text { Our marketing decisions are based more on informal customer } \\
\text { feedback rather than formal market research }\end{array}$ & 3.4631 & 1.16634 \\
\hline I3 & $\begin{array}{l}\text { It is important to rely on intuition when making marketing } \\
\text { decision }\end{array}$ & 3.2217 & 1.25122 \\
\hline $\mathrm{C} 1$ & $\begin{array}{l}\text { Customer demands are usually the reason why we introduce } \\
\text { new product and/ or service }\end{array}$ & 4.9012 & 0.90122 \\
\hline $\mathrm{C} 2$ & $\begin{array}{l}\text { We usually introduce new product and service based on the } \\
\text { recommendation from our suppliers }\end{array}$ & 4.9831 & 0.98316 \\
\hline $\mathrm{C} 3$ & We highly rely on experience when making marketing decision & 4.7436 & 0.74367 \\
\hline EM1 & $\begin{array}{l}\text { Growth orientation is an important factor in building business } \\
\text { success }\end{array}$ & 4.5148 & 0.63131 \\
\hline EM2 & $\begin{array}{l}\text { Opportunity orientation is an important factor in building } \\
\text { business success }\end{array}$ & 4.4852 & 0.60739 \\
\hline EM3 & $\begin{array}{l}\text { Total customer focus is an important factor in building business } \\
\text { success }\end{array}$ & 4.5 & 0.63148 \\
\hline EM4 & $\begin{array}{l}\text { Value Creation Through Networking is an important factor in } \\
\text { building business success }\end{array}$ & 4.5 & 0.67678 \\
\hline EM5 & $\begin{array}{l}\text { Informal Market Analysis is an important factor in building } \\
\text { business success }\end{array}$ & 4.3374 & 0.67909 \\
\hline EM6 & $\begin{array}{l}\text { Closeness To The Market is an important factor in building } \\
\text { business success }\end{array}$ & 4.4113 & 0.71372 \\
\hline
\end{tabular}

Source: Data processing, 2020

Almost all responses from respondents for all questions have the mean of above 4, only the mean for the answers to opportunity orientation dimension question, which is "Our marketing effort leads the customer, and not to respond" and the three questions for all dimensions of informal analysis dimension that have the answers mean between 3 and 3.5 , which includes "Introducing new product or service usually only involves limited research and formal market analysis", "Our marketing decisions are based more on informal customer feedback rather than formal market research", and "It is important to rely on intuition when making marketing decision".

\section{FINDINGS AND DISCUSSION}

\section{Validity and reliability test}

The validity test using Pearson correlations shows that the value of calculated $r$ is $>$ table $r$, based on the significance test 0.01 (2-tailed), which means that the items above are valid. The reliability test was conducted using Cronbach's alpha 
which shows the value of 0.876 , higher than 0.6 which means that it is reliable and that the instrument used in the study to obtain information can be relied on as a tool to collect data and can reveal actual information in the field.

\section{Hypothesis testing}

The t-test differences test is used to prove that there is a difference in the entrepreneurial marketing behavior between companies with small and large scale, based on Table 3 and Table 4 as follows.

Table 3. Group statistics

\begin{tabular}{cccccc}
\cline { 2 - 5 } & CompSize & $\mathrm{N}$ & Mean & $\begin{array}{c}\text { Std. } \\
\text { Deviation }\end{array}$ & $\begin{array}{c}\text { Std. Error } \\
\text { Mean }\end{array}$ \\
\cline { 2 - 5 } EntrMark2 & Founder & 280 & 4.3768 & 0.55155 & 0.03290 \\
& Profesional & 126 & 4.514 & 0.3806 & 0.03391 \\
\hline
\end{tabular}

Table 3 shows that there are $280(68.9 \%)$ companies managed by founders and $126(31 \%)$ companies managed by professionals as the respondents, with a mean of 4.37 in companies managed by founders and 4.5 in companies managed by professionals. The standard deviations for the two are 0.55 and 0.38 respectively, which indicates that the respondents' responses tend to be homogeneous.

Table 4. t-test difference testing

\begin{tabular}{|c|c|c|c|c|c|c|c|c|c|c|}
\hline \multirow{5}{*}{$\begin{array}{l}\text { Entry } \\
\text { Mark2 }\end{array}$} & \multirow{4}{*}{$\begin{array}{c}\text { Equal } \\
\text { variances } \\
\text { assumed } \\
\text { Equal } \\
\text { variances } \\
\text { not assumed }\end{array}$} & \multicolumn{5}{|c|}{ Levene's Test for Finality } & \multicolumn{4}{|c|}{ of Variances } \\
\hline & & $\mathrm{F}$ & $\begin{array}{l}\mathrm{Si} \\
\mathrm{g} .\end{array}$ & $\mathrm{t}$ & $\mathrm{df}$ & $\begin{array}{c}\text { Sig. } \\
(2- \\
\text { tailed) }\end{array}$ & $\begin{array}{c}\text { Mean } \\
\text { Difference }\end{array}$ & $\begin{array}{c}\text { Std. } \\
\text { Error } \\
\text { Differen }\end{array}$ & $\begin{array}{r}95 \% \\
\text { Inte } \\
\mathrm{D}\end{array}$ & $\begin{array}{l}\text { idence } \\
\text { of the } \\
\text { nce }\end{array}$ \\
\hline & & & & & & & & & Lower & Upper \\
\hline & & 30.541 & 0 & -3.594 & 404 & 0.00 & -0.19464 & 0.05416 & -0.30112 & -008817 \\
\hline & & & & -4.116 & 337.749 & 0.00 & -0.19464 & 0.04729 & -0.28766 & -010163 \\
\hline
\end{tabular}

Table 4 shows EM differences test analysis for companies managed by founders and companies managed by professionals by using Levene Test in independent t-test, Sig value (2-tailed) or p-value. In the test above, the p-value is 0.007 , which is $<0.05$ indicating that there is a meaningful or significant difference statistically in probability 0.05 . The magnitude of the difference in mean of the two groups is -0.194 . Since the value is negative, it means that the first group, which consists of companies managed by founders, has a lower mean than the group of companies managed by professionals, or companies managed by founders have lower entrepreneurial marketing behavior compared to companies managed by professionals.

As for Table 5, Table 6, and Table 7, multiple regression tests were conducted to analyze whether the six dimensions have a significant impact on entrepreneurial marketing behavior of companies managed by founders compared to companies managed by professionals.

Table 5. Model summary

\begin{tabular}{ccccc}
\hline Model & $\mathrm{R}$ & R Square & Adjusted R Square & $\begin{array}{c}\text { Std. Error of the } \\
\text { Estimate }\end{array}$ \\
\hline Founder & $.767^{\mathrm{a}}$ & .588 & .579 & .33896 \\
Profesional & $.666^{\mathrm{a}}$ & .444 & .416 & .31402 \\
\hline
\end{tabular}

Source: output statistic

Based on table 5, it shows that the R-value is 0.767 and R-squared is 0.588 for companies managed by founders, and for the group of companies managed by founders, the values are R of 0.666 and R-squared of 0.44 , which shows that the percentage contribution of the impact of the independent variable (which are: Growth Orientation, Opportunity Orientation, Total customer focus, Value creation Networking, Informal Market Analysis, Closeness to The Market) on EM behavior is $58.8 \%$ for companies managed by founders, and $44.4 \%$ for companies managed by professionals. 
Table 6. ANOVA

\begin{tabular}{|c|c|c|c|c|c|c|}
\hline Type of Com & & Sum of Squares & $\mathrm{df}$ & Mean Square & $\mathrm{F}$ & Sig. \\
\hline \multirow{3}{*}{ Founder } & Regression & 9.360 & 6 & 1.560 & 15.821 & $.000^{\mathrm{b}}$ \\
\hline & Residual & 11.735 & 119 & .099 & & \\
\hline & Total & 21.095 & 125 & & & \\
\hline \multirow{5}{*}{ Professional } & 1 & Residual & 6 & 6.042 & 89.404 & $.000 \mathrm{~b}$ \\
\hline & Regression & Total & 178 & .068 & & \\
\hline & & 36.250 & 184 & & & \\
\hline & & 12.029 & & & & \\
\hline & & 48.279 & & & & \\
\hline
\end{tabular}

Source: output statistic

Based on Table 6, it shows that the significant value is 0.000 for both companies managed by founders and companies managed by professionals, which means that there is a significant impact of Growth Orientation, Opportunity Orientation, Total customer focus, Value creation Networking, Informal Market Analysis, Closeness to The Market simultaneously towards EM behavior of companies managed by founders as well as companies managed by professionals.

Tabel 7. Coefficient

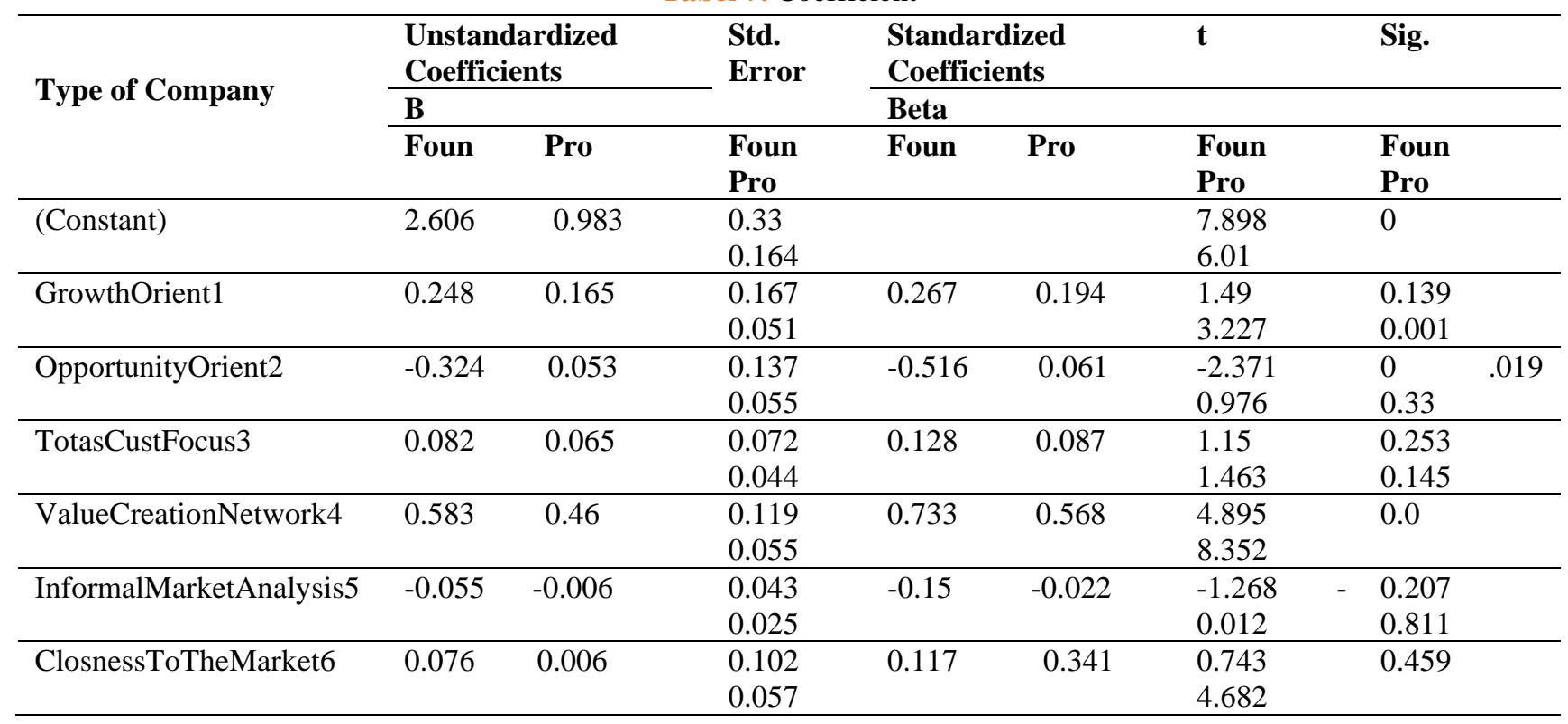

Table 7 shows that some of the six dimensions have a significant impact on entrepreneurial marketing behavior. In companies managed by founders, only two dimensions are significant, which are opportunity orientation and value creation networking. As for companies managed by professionals, only three dimensions are significant which are growth orientation, value creation networking, and closeness to the market, and they are significant since their significance values are less than 0.05. Value creation networking variable is also a dimension that is most dominant for companies managed by founders with a beta value of 0.583 , which is similar to companies managed by professionals with a beta value of 0.46 .

\section{DISCUSSION}

The result of the study shows that there is a difference between entrepreneurial marketing behavior of companies managed by founders and companies managed by professionals, in which companies managed by founders have lower entrepreneurial marketing behavior compared to companies managed by professionals. The result also presents that value creation networking is the most dominant dimension for both companies managed by founders and companies managed by professionals,. Companies managed by professionals used a different approach in pursuing their market opportunity. Companies managed by professionals pursue opportunities by relying on speed, flexibility, and ability to satisfy market niche, whereas companies managed by founders pursue opportunities by relying on financial resources and human resources (Dean et al., 1998).

Companies managed by professionals have a marketing decision-making process that tends to be more opportunistic, flexible, and innovative with a clear target. Companies can improvise and make sudden changes in decision-making patterns when involved with their market. As a result, they have the ability to react faster towards changes in the 
environment and a tendency to capture new opportunities at a faster pace than companies managed by founders (Carson \& McCartan-Quinn, 1995; Chen \& Hambrick, 1995). Companies managed by professionals have less dominant decisionmakers compared to companies managed by founders. As a result, marketing decisions and strategies of companies managed by founders can be directly impacted by the decision maker's personal interest (Brush \& Chaganti, 1998).

Finally, companies managed by professionals have a more flat organizational structure compared to companies managed by founders, and this makes them closer to the customers. Company personnel of all levels in professional companies has the potential to be involved in individual level and face to face interaction with customers (Carson et al, 1995). It is also relatively easy for professional companies to access market information through direct manners (Hisrich, 1992). As a result, companies managed by professionals tend to invest in building a personal relationship with their main customers to build strong contact with customers as compared to companies managed by founders (Meziou, 1991). This research also found that companies managed by professionals are more oriented towards value creation to build networking in marketing (Bjerke \& Hultman, 2002)

\section{CONCLUSION}

Findings in this study prove that companies managed by founders have lower entrepreneurial marketing behavior compared to companies managed by professionals. However, companies managed by founders and professionals both show value creation networking as the most dominant dimension.

The finding in which characteristics of companies managed by founders and professionals are the suitable determining factor for EM practices gave an important theoretical contribution to the development of EM knowledge. This study also offers several implications for future studies. The result of the analysis shows that companies managed by founders are less involved in the approach with EM market dimension compared to companies managed by professionals. The findings of this study indicate that companies managed by founders do not have a well-defined market or established customer base, therefore they rely less on market demand/ market information compared to companies managed by professionals when introducing their new products. These findings imply that future studies might need to consider investigating how far EM can help mitigate the impact of responsibility on corporate novelty and to identify the best EM practice that needs to be adopted by companies so that they can be sustainable in the long run.

\section{REFERENCES}

Becherer, R. C., Haynes, P. J., and Helms, M. M. (2008). An Exploratory Investigation of Entrepreneurial Marketing. Journal of Business and Entrepreneurship, 20, 44-64.

Bjerke, B. and Hultman, C.M. (2002). Entrepreneurial Marketing: The Growth of Small Firms in the New Economic Era. Edward Elgar, Cheltenham.

Brush, C.G. and Chaganti, R. (1998). Businesses without glamour? an Analysis of resources on performance by size and age in small service and retail firms. Journal of Business Venturing, 14 (3), 233-257.

Busenitz, L. and Barney, J. (1997). Differences between entrepreneurs and managers in large organizations: biases and heuristics in strategic decision-making. Journal of Business Venturing, 12 (1), 9-30.

Carson, D., Cromie, S., McGowan, P. and Hill, J. (1995). Marketing and Entrepreneurship in SMEs: An Innovative Approach. PrenticeHall, London.

Carson, D. and Grant, K. (1998). SME marketing competencies: a definition and some empirical evidence in Hills, G.E. and Miles, M. (Eds). Research at the Marketing/Entrepreneurship Interface. University of Illinois at Chicago, Chicago, IL, 173-186.

Carson, D. and McCartan-Quinn, D. (1995). Non-practice of theoretically based marketing in small business: issues arising and their implications. Journal of Marketing Theory and Practice, 3 (4), 24-32.

Chen, M.J. and Hambrick, D.C. (1995). Speed, stealth, and selective attack: how small firms differ from large firms in competitive behaviour. Academy of Management Journal, 38 (2), 453-482.

Collinson, E., \& Shaw, E. (2001). Entrepreneurial marketing - a historical perspective on development and practice. Management Decision ,39(9), 761-766.

Dean, T.J., Brown, R.L. and Bamford, C.E. (1998), Differences in large and small firm responses to environmental context: strategic implications from a comparative analysis of business formations. Strategic Management Journal, 19 ( 8), 709-728.

Erikson, T. (2002), "Entrepreneurial capital: the emerging venture's most important asset and competitive advantage", Journal of Business Venturing, ( 17 No. 3, 275-290.

Gilmore, A., Carson, D., \& Grant, K. (2001). SME marketing in practice. Marketing Intelligence \&Planning, 19 (1), 6-11.

Hacioglu, Gungor.,Selim S. Eren., M. Sule Eren., Hale Celikkan. (2012). The effect of entrepreneurial marketing on firms' innovative performance in Turksih SMEs. Social and Behavioral Sciences, (58), $871-878$.

Hambrick, D. and Mason, P. (1984), Upper echelons: the organization as a reflection of its top managers. The Academy of Management Review, 9 (2), 193-206.

Hills, G. and Singh, R. (1998). Opportunity recognition: a survey of high performing and representative entrepreneurs in Hills, G.E. and Miles, M. (Eds). Research at the Marketing/Entrepreneurship Interface, University of Illinois at Chicago, Chicago, IL, 249268.

Hisrich, R. (1992). The need for marketing in entrepreneurship. Journal of Business \& Industrial Marketing, 7 (3), 53-57.

Hills, G. and Hultman, C. (1999). Marketing behaviour in growing firms: a challenge to traditional marketing knowledge in Hills, G.E., Siu, W. and Malewicki, D. (Eds). Research at the Marketing/Entrepreneurship Interface. University of Illinois at Chicago, Chicago, IL, 14-29.

Jones, R., \& Rowley, J. (2011). Entrepreneurial marketing in small businesses: A conceptual exploration. International Small Business Journal, 29 (1), 25-36. 
Kraus, S., Filser, M., Eggers, F., Hills, G. E., \& Hultman, C. M. (2012). The entrepreneurial marketingdomain: A citation and cocitation analysis. Journal of Research in Marketing and Entrepreneurship, 14 (1), 6-26.

Kilenthong, Pitsamorn., Gerald E. Hills., Claes M. Hultman (2015), An empirical investigation of entrepreneurial marketing dimensions, Journal of International Marketing Strategy, 3 (1), 1-18.

Li, Y-H., Huang, J-W.and Tsai, M-T. (2009). Entrepreneurial orientation and firm performance:the role of knowledge creation process. Industrial Marketing Management. 38 (4), 440-449.

Meziou, F. (1991). Areas of strength and weakness in the adoption of the marketing concept by small manufacturing firms. Journal of Small Business Management, 29 (4), 72-78.

Miles, M.P. and Darroch, J. (2006). Large firms, entrepreneurial marketing processes, and the cycle of competitive advantage. European Journal of Marketing, 40 (5/6), 485-501.

Morris, M., Schindehutte, M. and LaForge, R. (2002). Entrepreneurial marketing: a construct for integrating emerging entrepreneurship and marketing perspectives. Journal of Marketing Theory and Practice, 10 (4), 1-19.

Randoy, T. and Goel, S. (2003). Ownership structure, founder leadership, and performance in Norwegian SMEs: implications for financing entrepreneurial opportunities. Journal of Business Venturing, 18 (5), 619-637.

Sheth, Jagdish, Bruce I. Newman \& Barbara L. Gross. (1991). Why We Buy What We Buy: a Theory of Consumption Values. Journal of Business Research, 22 (2), 159-170.

Stasch, S. (1999), "Guerilla marketing in new venture marketing strategies", in Hills, G.E., Siu, W. and Malewicki, D. (Eds), Research at the Marketing/Entrepreneurship Interface, University of Illinois at Chicago, Chicago, IL, 57-67.

Thomas, L.C., Painbéni, S. and Barton, H. (2013). Entrepreneurial marketing within the French wine industry. International Journal of Entrepreneurial Behavior \& Research, 19 (2), 238-260.

\section{ACKNOWLEDGEMENT}

The authors would like to thank Direktorat Riset dan Pengabdian Masyarakat Direktorat Jenderal Riset dan Pengembangan Kementerian Riset, Teknologi, dan Pendidikan Tinggi for Funding in this research and the anonymous reviewers for their insightful suggestions and careful reading of the manuscript.

\section{AUTHOR BIOGRAPHY}

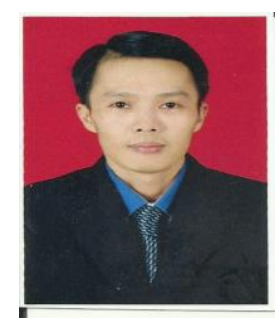

Hendro Susanto S.E., M.M., earned his Bachelor degree in Economics (S.E) from Widya Mandala University Surabaya in 1998, then in 2003 earned his Master of Management (M.M.) degree at Widya Mandala University Surabaya. Currently working as a lecturer as well as serving as chairman of accounting study program at Ciputra University surabaya. The author is also active in editorialing books, journals, and intellectual property right. The author can be reached at the email address: hendro.susanto@ciputra.ac.id

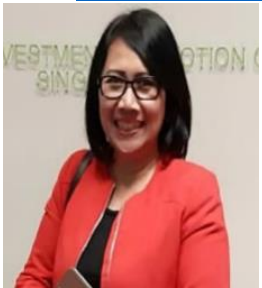

Prof. Dr. Dra. Ch Whidya Utami, MM., CLC., CPM (A) holds a bachelor's degree in Economics (S.E) at Airlangga University in 1991, a Master of Management (M.M.) at Airlangga University in 1994, and a Doctoral Program (Dr.) at Airlangga University in 2006. Currently working as a lecturer as well as serving as dean at Ciputra University surabaya. The author is also active in editorialing books, journals, and intellectual property right. The author can be reached at the email address: whidyautami@ciputra.ac.id. 